\title{
Challenges and Opportunities to Scale Up Check for updates Cardiovascular Disease Secondary Prevention in Latin America and the Caribbean
}

\author{
Álvaro Avezum*, Pablo Perel ${ }^{\dagger}$, Gustavo B. F. Oliveira*, Patricio Lopez-Jaramillo ${ }^{\ddagger}$, Gustavo Restrepo ${ }^{\S}$, \\ Fleetwood Loustalot", Andrea Srur ${ }^{\pi}$, Reinaldo de La Noval ${ }^{\#}$, Kenneth I. Connell**, Salvador Cruz-Flores ${ }^{\dagger \dagger}$, \\ Lenildo de Moura ${ }^{\ddagger \ddagger}$, Gabriela Castellac ${ }^{\S \S}$, Antonio C. Mattos*, Pedro Ordunez ${ }^{\ddagger}$
}

São Paulo, Brazil; Geneva, Switzerland; Bucaramanga, Colombia; Mexico City, Mexico; Atlanta, GA, USA; Santiago, Chile; Havana, Cuba; Port of Spain, Trinidad and Tobago; Dallas, TX, USA; Washington, DC, USA; and Rio de Janeiro, Brazil

Cardiovascular disease (CVD) is the leading cause of death throughout the world; however, a reduction of $21 \%$ (age-standardized cardiovascular mortality rates per 100,000 inhabitants) was observed between 1990 and 2010, with more substantial reductions in CVD mortality evident in high-income countries ( $\sim 42 \%$ reduction in CVD deaths) (Table 1) [1,2].

\section{CARDIOVASCULAR DISEASE BURDEN IN LATIN AMERICA AND THE CARIBBEAN}

In the Americas, CVD represents about $38 \%$ of noncommunicable disease (NCD) deaths and is the leading cause of death, with 1.6 million deaths per year, one-half million occurring before age 70 [3]. Although mortality due to CVD in the Americas declined 19.2\% from 2000 to 2007, higher median CVD mortality was found in lowincome $(242$ per 100,000) and medium-income (186 per $100,000)$ countries, compared with high-income countries (154 per 100,000) [4]. Between 2000 and 2010, premature CVD mortality $(<70$ years of age $)$ in the Americas decreased by $21 \%$, with a statistically significant $2.5 \%$ average annual decline in the rate of change in the final 5 years. Declines in mortality from ischemic vascular disease (overall, 25\%; men, 24\%; women, 26\%) and cerebrovascular disease (overall, 27\%; men, 26\%; women, $28 \%$ ) were observed during the first decade of this century. These declines were not uniform across all countries, with notable disparities in country-specific premature mortality rates (region average, 132.7 per 100,000 ), including rates above 200 per 100,000 in Guyana, Trinidad and Tobago, the Dominican Republic, Bahamas, and Brazil [5]. Although, substantial decreases in CVD mortality rates have been seen in most regions, including the Americas from 1990 to 2013, the CVD burden, and specifically the absolute number of cases and deaths have risen in some but not all countries of the region [6]. CVD disproportionately affects the poorest population sectors [7], affecting families, communities, and governments due to treatment costs and potential years of life and productivity lost due to premature death and disability $[8,9]$. Therefore, the direct and indirect costs of these diseases absorb resources that could otherwise be spent in health promotion efforts at the community and clinical levels [7].

In terms of the global economic burden, direct and indirect costs of CVD were estimated to be US $\$ 863$ billion in 2010, potentially rising to US $\$ 1.04$ trillion by 2030 [10]. Even countries such as Brazil, Chile, Mexico, Argentina, and Peru, which experienced some economic growth in recent years, lack economic assets to efficiently provide resources to prevent and manage CVD [11]. A comprehensive approach to CVD prevention and management is needed for long-term improvements in cardiovascular health. This report focuses on efforts to improve secondary prevention using existing frameworks, tailored to the Latin American and Caribbean (LAC) context.

\section{THE FRAMEWORK OF}

\section{CVD SECONDARY PREVENTION}

Secondary prevention of CVD can be defined as the use of intensive risk-reduction therapies and adoption of healthy lifestyle behaviors in patients with established coronary and/or other atherosclerotic vascular diseases. This would include peripheral artery disease, atherosclerotic aortic disease, and carotid and cerebral artery disease with clinical benefits of $75 \%$ estimated efficacy. Efficacy with these outcomes has been assessed by a variety of outcomes, including improved survival, reduced recurrent events, the need for revascularization procedures, and improved quality of life [12-14]. Risk-reduction therapies and healthy lifestyle changes include pharmacological and nonpharmacologic interventions. Examples of pharmacologic interventions for these populations include antiplatelet agents, beta-blockers, angiotensin-converting enzyme (ACE) inhibitors or angiotensin-receptor blockers (ARB), 3-hydroxy-3-methy-glutaryl-coenzymeA reductase inhibitors (e.g., statins), and pharmaceutical therapy for tobacco cessation. Examples of nonpharmacological interventions include smoking cessation counseling, physical activity, and healthy diet. Both pharmacologic and nonpharmacologic interventions aim to reduce the probability
The findings and conclusions in this report are those of the authors and do not necessarily represent the official position of the Pan American Health Organization or the U.S. Centers for Disease Control and Prevention. This paper is a product of a joint consultation meeting with important contributions from several international organizations (Pan American Health Organization, World Heart Federation, Latin American Society of Hypertension, Inter-American Society of Cardiology, Caribbean Public Health Agency, Center for Disease Prevention and Control) and representatives of Ministries of Health of selected countries (Brazil, Chile, Cuba) held in São Paulo, Brazil at the end of 2015.

The authors report no relationships that could be construed as a conflict of interest.

From the *Dante Pazzanese Institute of Cardiology, São Paulo, Brazil; †World Heart Federation, Geneva, Switzerland; łLatin American Society of Hypertension, Bucaramanga, Colombia; $\S$ Inter-American Society of Cardiology, Mexico City, Mexico; ||Centers for Disease Prevention and Control, Atlanta, GA, USA; $\uparrow$ Ministry of Health, Chile, Santiago, Chile; \#Ministry of Health, Havana, Cuba; ${ }^{* *}$ Caribbean Public Health Agency Hypertension Guidelines Committee, Port of Spain, Trinidad and Tobago; ††American Heart Association, Dallas, TX, USA; $\ddagger$ Pan American Health Organization, Washington, DC, USA; and the $\S \S$ Ministry of Health, Rio de Janeiro, Brazil. Correspondence: Álvaro Avezum (avezum@ yahoo.com)

GLOBAL HEART C 2018 World Heart Federation (Geneva). Published by Elsevier Ltd. All rights reserved. 
VOL. 13 , NO. 2,2018 ISSN 2211-8160/ $\$ 36.00$. http://dx.doi.org/ $10.1016 /$ j.gheart.2017.05.002

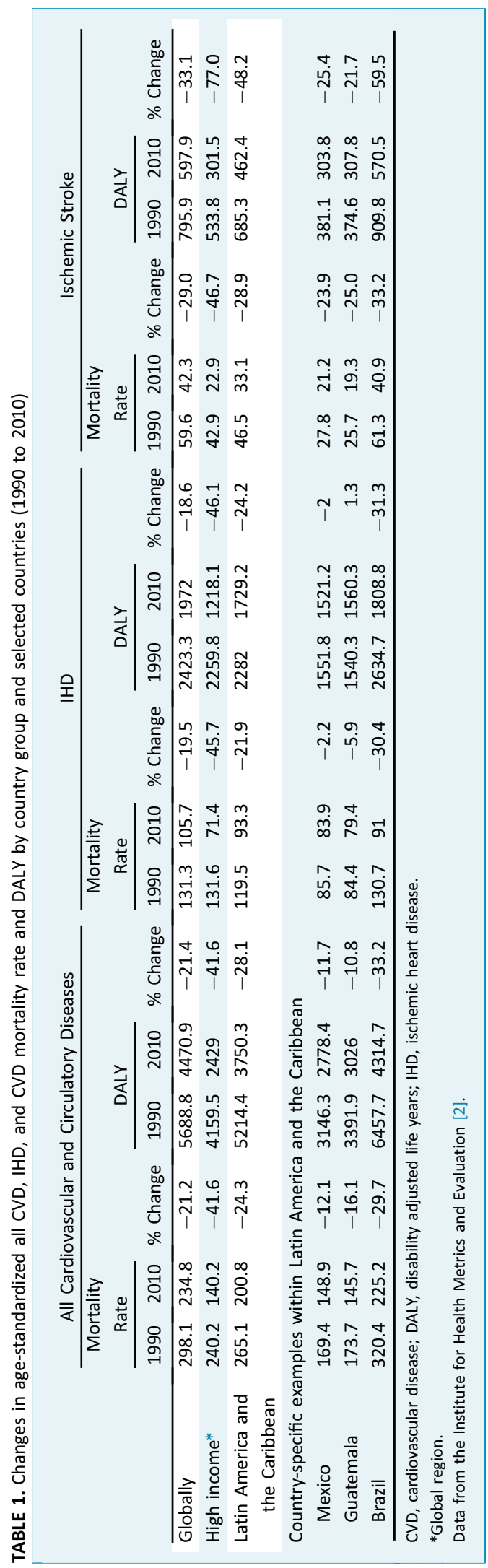

of recurrent cardiovascular events in patients with clinically evident atherosclerotic cardiovascular disease [15]. Moreover, clinical practice guidelines for the management of care with appropriate updates have been periodically published by several medical societies to guide physician prescription of proven, effective treatments in comprehensive CVD care [12,16-23]. Optimal risk factor management through nonpharmacologically based approaches (Table 2) may include tobacco cessation counseling, regular participation in physical activity, achieving a healthy diet, limited alcohol intake, and weight management; with clinical outcome improvements in blood pressure control, lipid management, and diabetes control [12,15,24-28]. Although these interventions have been shown to be effective, their uptake by patients can be challenging, and clinical and public health programs are encouraged to adapt resources to the culture and capability of those they serve. Programs addressing these areas are often composed of a multidisciplinary team of providers and should include individual level interventions using targeted education and behavior modification programs to counterbalance the "continuum" of the atherosclerotic process. Populationwide interventions (e.g., limiting exposure to secondhand tobacco smoke, sodium reduction) to reduce exposures to risk factors should complement individualized interventions that support risk factor management.

\section{CVD SECONDARY PREVENTION IN LATIN AMERICA AND THE CARIBBEAN: A SITUATION ANALYSIS}

A large body of robust evidence to guide therapeutic decision making and enhance long-term adherence after an acute episode of CVD, such as ST-segment elevation myocardial infarction, non-ST-segment elevation acute coronary syndromes, or revascularization procedures exists. Despite this, we frequently observe substantial discrepancies between the evidence-based recommendations and what is actually delivered in clinical practice. This can be appropriately documented based on contemporary realworld data on the use of beneficial secondary prevention medications among several geographic regions, including LAC. Examples include clinical as well as communitybased studies. The REACH (REduction of Atherothrombosis for Continued Health) registry included data from North America, Europe, Australia, Asia, Latin America (Brazil, Chile, Mexico, Panama, Costa Rica, Dominican Republic, Ecuador, Guatemala, and Peru), and the Middle East. The use of secondary prevention medications was ascertained among 32,247 patients. Among these patients, a significant gap was detected between clinically indicated and actual rates of use at the first visit assessment and after 3 years of follow-up: aspirin alone (baseline: $56.6 \%$ and 3year follow-up: 56.9\%); aspirin plus another antiplatelet agent $(14.5 \%$ and $12.8 \%)$; other antiplatelet agents alone (13.6\% and $14.2 \%$ ); and statins (68.3\% and $71.9 \%$ ) [29]. Compared with patients in North America in the REACH registry, patients from Latin America and Asia were less 
TABLE 2. Recommendations for secondary prevention as AHA/ACC guideline, 2011

\begin{tabular}{|c|c|}
\hline Area for Intervention & Goal \\
\hline Smoking & Complete cessation. No exposure to environmental tobacco smoke. \\
\hline Blood pressure control & $<140 / 90 \mathrm{~mm} \mathrm{Hg}$ \\
\hline Lipid management & $\begin{array}{l}\text { Treatment with statin therapy; use statin therapy to achieve an LDL-C of }<100 \mathrm{mg} / \mathrm{dl} \text {; for very high- } \\
\text { risk patients an } \mathrm{LDL}-\mathrm{C}<70 \mathrm{mg} / \mathrm{dl} \text { is reasonable; if triglycerides are } \geq 200 \mathrm{mg} / \mathrm{dl} \text {, non-HDL-C } \\
\text { should be }<130 \mathrm{mg} / \mathrm{dl} \text {, whereas non-HDL-C }<100 \mathrm{mg} / \mathrm{dl} \text { for very high-risk patients is } \\
\text { reasonable. }\end{array}$ \\
\hline Physical activity & At least 30 min, 7 days per week (minimum 5 days per week) \\
\hline Weight management & $\begin{array}{l}\text { Body mass index: } 18.5 \text { to } 24.9 \mathrm{~kg} / \mathrm{m}^{2} \\
\text { Waist circumference: women }<35 \text { inches }(<89 \mathrm{~cm}) \text {, men }<40 \text { inches }(<102 \mathrm{~cm})\end{array}$ \\
\hline $\begin{array}{l}\text { Type } 2 \text { diabetes mellitus } \\
\text { management }\end{array}$ & $\begin{array}{l}\text { Recommendations are for prevention of cardiovascular complications, based on lifestyle } \\
\text { modification, weight management, blood pressure control, lipid management, and } \\
\text { pharmacotherapy for all diabetes patients. }\end{array}$ \\
\hline $\begin{array}{l}\text { Medications based on } \\
\text { evidence }\end{array}$ & $\begin{array}{l}\text { Must be considered based on clinical condition of the patient, but the combination of them should } \\
\text { be applied to all patients on secondary prevention: antiplatelet agents/anticoagulants; renin- } \\
\text { angiotensin-aldosterone system blockers; ACE inhibitors; ARB; aldosterone blockade; beta- } \\
\text { blockers. }\end{array}$ \\
\hline Influenza vaccination & $\begin{array}{l}\text { Should be applied to all patients with cardiovascular disease an annual influenza vaccination } \\
\text { program. }\end{array}$ \\
\hline Depression & $\begin{array}{l}\text { It is reasonable to screen for depression if patients have access to case management, in } \\
\text { collaboration with their primary care physician and a mental health specialist. }\end{array}$ \\
\hline Cardiac rehabilitation & $\begin{array}{l}\text { All patients with ACS or postintervention procedures should be referred to a cardiac rehabilitation } \\
\text { program. Home-based programs have similar results as compared with supervised, center-based } \\
\text { program for low-risk patients. }\end{array}$ \\
\hline
\end{tabular}

ACC, American College of Cardiology; ACE, angiotensin-converting enzyme; ACS, acute coronary syndrome; AHA, American Heart Association; ARB, angiotensin-receptor blocker; HDL-C, high-density lipoprotein cholesterol; LDL-C, low-density lipoprotein cholesterol.

likely to be fully adherent to guideline-based treatments at 4 years [30]. Data from the large community-based PURE (Prospective Urban Rural Epidemiology) study have provided relevant assessment on the use of secondary prevention therapies across broad geographic and income levels. The use of effective secondary preventive medications (antiplatelet agents, beta-blockers, ACE inhibitors or ARB, and statins) in 153,996 adults ages 35 to 70 years with a history of coronary heart disease or stroke, from rural and urban communities in countries classified at various income levels by the World Bank has been evaluated. Few patients in the study were taking antiplatelet agents (25.3\%), beta-blockers (17.4\%), ACE inhibitors or ARB (19.5\%), or statins (14.6\%). Furthermore, use was lowest in low-income countries $(8.8 \%, 9.7 \%, 5.2 \%$, and $3.3 \%$, respectively) [31].

Recent data from the PURE study have also shown poor adoption of healthy lifestyle behaviors among those with known CVD, emphasizing the urgent need of efforts to implement the nonpharmacologically based interventions. For example, among 7,519 individuals with self-reported coronary heart disease or stroke, a substantial proportion continued some level of tobacco use following their event (18.5\%), only $35.1 \%$ participated in high levels of physical activity and only about $40 \%$ had diets classified as healthy. Changes in dietary habits may be a significant barrier in many environments, particularly low-income countries. In addition, 14\% did not undertake any of these 3 key healthy lifestyle behaviors and only $4.3 \%$ were classified as achieving all 3 recommended healthy behaviors. Variations in participation in healthy lifestyle behaviors were seen among different subgroups. For example, whereas over $50 \%$ reported smoking cessation during the period assessed, differences were noted among highincome countries (74.9\%), upper-middle-income countries (56.5\%), low-middle-income countries (42.6\%), and low-income countries (38.1\%) [32]. The existing evidence shows that lifestyle modifications to reduce the risk of recurrent CVD events are not being maximized, and these could be implemented alongside long-term pharmacological management of CVD. However, current approaches to modifying lifestyle behaviors, based on individual counseling, are expensive and only modestly effective, particularly among lower income countries, with significant barriers in health system and clinical capacity, broader approaches should be considered [31].

Overall, each year, millions of individuals survive ischemic heart disease or stroke events. This creates substantial clinical and public health challenges in the provision of CVD risk factor management, availability and affordability of effective therapies, adherence to prescribed medications, and available financial and human resources to care for individuals. Secondary prevention of CVD requires a comprehensive system that includes increased 
patient awareness, prescription of evidenced-based treatments using standardized approaches, patient adherence, and functional health systems; all of which are influenced by local socioeconomic factors. A fundamental aspect of improving CVD care is the concept of individual and system level factors being strongly influenced by the existence of effective national policies aimed to control NCD. Many efforts had been made by international organizations, such as the World Health Organization (WHO) and the Pan American Health Organization (PAHO), along with national organizations and medical societies, to prevent recurrence of CVD events in LAC by means of national and regional policies. Countries in the region have engaged in implementing those policies supported by $\mathrm{WHO}$ and $\mathrm{PAHO}$; however, there is much to be done to reduce the high burden of disease associated with CVD in LAC [33] Due to the existing economic diversity within and across the region, large geographic density and countries in different stages of epidemiological transition, LAC constitutes a vast field to build efficient and complementary models for secondary prevention of CVD.

\section{ROADMAP FOR SECONDARY PREVENTION IN LATIN AMERICA AND THE CARIBBEAN}

The World Heart Federation (WHF) Roadmaps are aligned with the WHO goal of reducing premature mortality from CVD by at least $25 \%$ by 2025 , and it may be viewed as a model to be locally customized for countries into currently established CVD prevention programs or to build implementation strategies where an efficient program is not yet implemented. The Secondary Prevention Roadmap in LAC aims to optimize actions to prevent and control CVD. Based on clear evidence of effectiveness, including feasibility and cost effectiveness, a practical roadmap identifies potential barriers (roadblocks) to implementation of prevention and control efforts and potential solutions for bypassing those barriers [15]. In some circumstances, proven therapies are neither available, nor affordable, and increased availability of proven therapies by means of expanded health coverage would potentially address that roadblock [34]. Finally, implementation of information and communication technology concerning the use of key therapies from simplified recommendations would maximize use of available resources for better treatment and patient adherence. The ehealth technology has the potential to be incorporated into daily clinical practice due to its low cost and being simple and widely available. About Latin America, around 150 million individuals use smartphones, and there are predictions that this number will increase up to 245 million users in 2019. Therefore, there is a good opportunity and potential utility of e-health technologies, particularly in terms of secondary prevention strategies in Latin America.

Two main actions are necessary to achieve the desired target for secondary prevention. First, priority interventions provided in a standardized algorithm (pharmacologic availability and use: ACE inhibitors, aspirin, statins, beta- blockers, tobacco cessation agents, and nonpharmacologic strategies that facilitate lifestyle modification, particularly smoking cessation) should be used broadly in a standardized manner by multidisciplinary teams in diverse settings. Second, systems of care should be structured to improve the likelihood of patient adherence to these interventions [15]. Table 3 identifies roadblocks and potential solutions for LAC that were the result of a joint consultation meeting between several international organizations (PAHO, WHF, the Latin American Society of Hypertension, the InterAmerican Society of Cardiology [IASC], the Caribbean Public Health Agency, the Centers for Disease Control and Prevention), and representatives of Ministries of Health of selected countries (Brazil, Chile, Cuba) held in São Paulo, Brazil, at the end of 2015. This joint consultation, which reviewed the applicability of the WHF Global Roadmap on Secondary Prevention for Latin America and explored opportunities to improve secondary prevention, concluded that WHF Roadmap framework is well aligned with the WHO strategy and priorities for NCD/CVD management as well as with the priorities of many other relevant global and regional organizations in this particular matter. In addition, this consultation highlighted that the WHF Roadmap offers an important opportunity to work in the coordinated manner at local and regional levels to coordinate efforts among between partners to scale up secondary prevention of CVD in the Americas.

The following actions should be prioritized to obtain the desirable outcomes (Figure 1): 1) integration of CVD secondary prevention interventions into the general framework of CVD/NCD management; 2) increasing the availability of health care professionals to provide recommendations to patients with known CVD; 3) simplifying the treatment of patients with known CVD; 4) ensuring that health care professionals are aware of and follow recommendations; 5) increasing the availability and affordability of key priority interventions; 6) helping patients to adhere to recommendations; 7) strengthening the governance of health care systems to enhance prevention; and 8) strengthening health information systems [15].

\section{LATIN AMERICAN CVD PREVENTION AND CONTROL PRIORITIES}

In 2006, in response to the regional and global concern about NCD, the Directing Council of PAHO approved a comprehensive regional plan for the prevention and control of NCD [35]. This program was operationalized through biannual plans aimed at achieving specific objectives, which included 4 lines of action: integrated management of NCD and risk factors; health promotion and disease prevention; surveillance; and policy and advocacy [33]. Since then, significant progress in implementing national chronic disease programs has been reported in the majority of countries [33].

In 2010, a regional consultation on cardiovascular health, led by PAHO, proposed a core set of priority 
TABLE 3. Roadblocks and potential solutions to achieve appropriate cardiovascular secondary prevention targets in LAC

\begin{tabular}{|c|c|c|c|c|}
\hline \multirow[b]{2}{*}{$\begin{array}{l}\text { Roadblock } \\
\text { Health care systems do not } \\
\text { efficiently track patients } \\
\text { with known CVD; poor/ } \\
\text { lack of integration } \\
\text { between CVD referral } \\
\text { centers and primary care. }\end{array}$} & \multicolumn{4}{|c|}{ Potential Solutions } \\
\hline & $\begin{array}{l}\text { Establish integrated } \\
\text { information systems } \\
\text { across different levels of } \\
\text { health care; create a } \\
\text { unique ID to } \\
\text { appropriately track those } \\
\text { with CVD. }\end{array}$ & $\begin{array}{l}\text { Physician/hospital report of } \\
\text { patient's clinical } \\
\text { diagnoses and status, } \\
\text { medications prescribed, } \\
\text { summary of } \\
\text { postdischarge plan for } \\
\text { long-term management } \\
\text { of care. }\end{array}$ & $\begin{array}{l}\text { Referral to rehabilitation } \\
\text { services; improve } \\
\text { schedule of follow-up } \\
\text { visits at outpatient clinics }\end{array}$ & $\begin{array}{l}\text { Education provided to the } \\
\text { patient and family: the } \\
\text { disease and possible } \\
\text { complications, } \\
\text { importanceof the use of } \\
\text { specific medications, } \\
\text { adoption of healthy } \\
\text { lifestyle }\end{array}$ \\
\hline $\begin{array}{l}\text { Patients with known CVD do } \\
\text { not have access to the } \\
\text { health care system. }\end{array}$ & $\begin{array}{l}\text { Increase appropriate access } \\
\text { to the health care system; } \\
\text { create an efficient plan } \\
\text { for continuous tracking } \\
\text { system to minimize cases } \\
\text { lost to follow-up. }\end{array}$ & $\begin{array}{l}\text { Strengthen the role of the } \\
\text { primary health care } \\
\text { system to support } \\
\text { secondary prevention of } \\
\text { CVD rare health system } \\
\text { level on cardiovascular } \\
\text { secondary prevention; } \\
\text { similar solutions to first } \\
\text { roadblock as described. }\end{array}$ & $\begin{array}{l}\text { Expand clinic operating } \\
\text { hours; schedule first and } \\
\text { follow-up visit in } \\
\text { collaboration with } \\
\text { patients; diversify } \\
\text { locations of health care } \\
\text { units, especially in rural } \\
\text { communities. }\end{array}$ & \\
\hline $\begin{array}{l}\text { Guidelines are not available } \\
\text { or recommendations are } \\
\text { too complex. }\end{array}$ & $\begin{array}{l}\text { Develop or translate a simple } \\
\text { set of recommendations } \\
\text { for the primary care } \\
\text { workforce. }\end{array}$ & $\begin{array}{l}\text { Clinical decision support } \\
\text { systems to guide } \\
\text { decision-making process } \\
\text { and remind providers of } \\
\text { key priority interventions. }\end{array}$ & $\begin{array}{l}\text { Utilizing e-health to its } \\
\text { maximum capacity. }\end{array}$ & \\
\hline $\begin{array}{l}\text { Priority interventions are not } \\
\text { available. }\end{array}$ & $\begin{array}{l}\text { Ensure priority interventions } \\
\text { are included in the } \\
\text { national list of essential } \\
\text { medicines. }\end{array}$ & $\begin{array}{l}\text { Establish a "core set" of } \\
\text { medications; ensure that } \\
\text { this core set is available } \\
\text { at the community level. }\end{array}$ & & \\
\hline $\begin{array}{l}\text { Priority interventions are not } \\
\text { affordable. }\end{array}$ & $\begin{array}{l}\text { Promote the use of quality } \\
\text { generic medications; } \\
\text { assess feasibility of } \\
\text { polypill/polycapsule to } \\
\text { enhance universal } \\
\text { coverage and improve } \\
\text { long-term adherence. }\end{array}$ & $\begin{array}{l}\text { Promote local manufacturing; } \\
\text { bulk purchasing and/or } \\
\text { efficient system to } \\
\text { streamline medication } \\
\text { supply; choose low-cost, } \\
\text { high-quality alterative. }\end{array}$ & $\begin{array}{l}\text { Provide financial and social } \\
\text { support for patients to } \\
\text { purchase priority } \\
\text { interventions. }\end{array}$ & \\
\hline
\end{tabular}


TABLE 3. Continued

\begin{tabular}{|c|c|c|c|c|}
\hline \multirow{2}{*}{$\begin{array}{l}\text { Roadblock } \\
\text { Patients are not aware of the } \\
\text { importance of and need } \\
\text { for long-term treatment. }\end{array}$} & \multicolumn{4}{|c|}{ Potential Solutions } \\
\hline & $\begin{array}{l}\text { Engage diverse health care } \\
\text { staff (e.g., pharmacy, } \\
\text { nurses) to education } \\
\text { patients and family about } \\
\text { the health condition; } \\
\text { promote continuous } \\
\text { education on } \\
\text { consequences, daily } \\
\text { activities of living, and } \\
\text { impact on survival. }\end{array}$ & $\begin{array}{l}\text { Public campaigns; } \\
\text { performance measures as } \\
\text { metrics to inform patients } \\
\text { and family; provider point } \\
\text { of care decision prompts } \\
\text { in risk factor review and } \\
\text { medication adherence. }\end{array}$ & $\begin{array}{l}\text { Empower patients to have a } \\
\text { key role in the decision- } \\
\text { making process (patient } \\
\text { advocacy), sharing } \\
\text { comments, and thoughts } \\
\text { with health care } \\
\text { providers. }\end{array}$ & \\
\hline $\begin{array}{l}\text { Patients do notremember to } \\
\text { follow recommendations. }\end{array}$ & $\begin{array}{l}\text { Use information and } \\
\text { communication } \\
\text { technology to remind } \\
\text { patients about key and } \\
\text { simple recommendations } \\
\text { (mHealth). }\end{array}$ & $\begin{array}{l}\text { Shift conversation away from } \\
\text { directly blaming patient } \\
\text { to one of mutual } \\
\text { understanding of need for } \\
\text { lifestyle changes to } \\
\text { manage and improve } \\
\text { chronic condition. }\end{array}$ & $\begin{array}{l}\text { Use patient-nominated, } \\
\text { nonprofessional } \\
\text { treatment supporters } \\
\text { (family and close friends } \\
\text { to come to the first visit } \\
\text { at the outpatient clinic } \\
\text { after the CV event). }\end{array}$ & $\begin{array}{l}\text { Encourage community } \\
\text { engagement and } \\
\text { ownership of health } \\
\text { promotion activities } \\
\text { through integration of } \\
\text { new technologies. }\end{array}$ \\
\hline $\begin{array}{l}\text { Patients with low health } \\
\text { literacy who do not know } \\
\text { what medication to take. }\end{array}$ & $\begin{array}{l}\text { Develop easy to interpret } \\
\text { medication labels (e.g., } \\
\text { symbols for dosing) and } \\
\text { educational materials. }\end{array}$ & $\begin{array}{l}\text { Include education of broader } \\
\text { social support network, } \\
\text { including family } \\
\text { members. }\end{array}$ & & \\
\hline
\end{tabular}

CV, cardiovascular; CVD, cardiovascular disease; LAC, Latin America and Caribbean.

interventions to improve cardiovascular health in the region and, since then, much progress has been reported. Policies related to improvements in smoke-free spaces were most likely to be implemented. Progress was apparent in surveillance of risk factors, actions to improve the quality of mortality data, and access to medication for hypertension among disadvantaged populations. However, significant challenges persist in many priority areas. For instance, on the prevention side, less than one-half of countries reported more focus and resources for cardiovascular health components of the NCD plans. What was also evident in that report was the limited progress on the clinical management of CVD. For example, less than 50\% of the countries reported clear progress on the following: emphasis of therapeutic control of hypertension; CVD risk assessment in primary care; public health programs for early recognition of CVD; institutional incentives for doctors to use clinical practice guidelines in hypertension management and for quality improvement of acute coronary syndrome [36].

\section{PROPOSAL FOR A REALISTIC AND EFFICIENT PREVENTION COALITION PLAN IN LATIN AMERICA}

Taking into account the heterogeneity of health systems, management strategies for CVD prevention, and patient adherence in LAC, a proposal for a coalition toward an efficient and integrated prevention plan will not be an easy task; however, this is indeed feasible. A common, comprehensive, regional, and country-applicable agenda is urgently needed and highly desirable for secondary prevention of CVD in LAC. To address the high burden of CVD in the region, a coalition plan should be developed. This would include the integrated efforts of clinical medicine, public health and health professional societies and organizations, government at all levels (federal, state, and municipal), patient organizations, universities, private initiatives, and international organizations such as PAHO and WHF. The guarantee of availability and accessibility of an essential set of medications is critical to moving forward with the secondary prevention of the CVD agenda. In this regard, the role of PAHO Strategic Fund would be relevant to support the efforts of countries to improve the access to high-quality and affordable, low-cost medications [37].

It would be very desirable that following this joint consultation meeting, the LAC region can move toward the construction of a regional plan to scale up the implementation of the CVD secondary prevention. Such a plan should start with a situational analysis in each country to properly and reliably assess the current landscape of secondary CVD prevention. The plan should focus on clear and measurable objectives, contain straightforward implementation actions, and include a core set of indicators for monitoring and evaluation.

\section{SIMPLE AND PRACTICAL GUIDELINES FOR HEALTH CARE PROVIDERS}

Guideline-based recommendations continue to be underused, and some observational studies have shown that low implementation in daily practice is associated with the high degree of complexity of the recommendations $[28,29,38]$. 
As a result, patients fail to benefit optimally from advances in health care and are exposed to unnecessary risks, and health care systems are exposed to unnecessary expenditures. The utilization of clinical practice guidelines is influenced by local barriers or facilitators for the individual clinician and the professional context. There are gaps between knowledge and application, and these could be linked to: 1) guidelines characteristics (e.g., format, external validity, and scientific basis); 2) physician factors that include knowledge, training, and agreement with guidelines; and 3) both physician and organizational environments [38]. Francke et al. [39] suggested that guidelines that are easy to understand and simple to use in daily practice are more likely to be fully implemented. Moreover, various characteristics of patients, health care professionals, and the environment may influence guideline implementation. It seems clear that effective strategies to improve guideline adherence that are based on multiple domains and broader approaches are more likely to be successful. WHO has promoted the use of a Package of Essential Noncommunicable disease interventions for primary health care in low-resource settings. In the context of CVD secondary prevention, the WHO Package of Essential Noncommunicable [40] should be considered as a simple and practical tool for health care providers that could be customized to address local needs. Technical guidance packages from WHO should also be considered to guide interventions, including those focused on CVD prevention and management (e.g., Global HEARTS [Technical Package For Cardiovascular Disease Management In Primary Health Care]), complemented by activities focused on sodium reduction (e.g., SHAKE [Technical Package For Salt Reduction]) and tobacco cessation (MPOWER [Technical Package To Defeat The Global Tobacco Epidemic]) [41].

\section{FINAL CONSIDERATION}

CVD imposes a heavy and lifelong burden in LAC. Availability of scientific evidence confirming efficacy of pharmacological and nonpharmacological interventions requires appropriate translation and implementation to fully recognize their benefits. The WHF $25 \times 25$ Roadmap aiming at reducing premature cardiovascular mortality, globally, includes 3 major components: smoking; hypertension; and cardiovascular secondary prevention. To achieve efficiently the proposed target, a coalition including academic, government, health organizations, private stakeholders, and civil society, including nongovernment organizations, must work together toward a better and more efficient system for cardiovascular care delivery in LAC. Therefore, there is a clear role for PAHO, WHF, and organizations such as the Inter-American Society of Cardiology to be responsible for organizing and harmonizing the CVD secondary prevention in Latin America. In that context, the IASC would have a crucial role leading the National Cardiology Societies in Latin America.

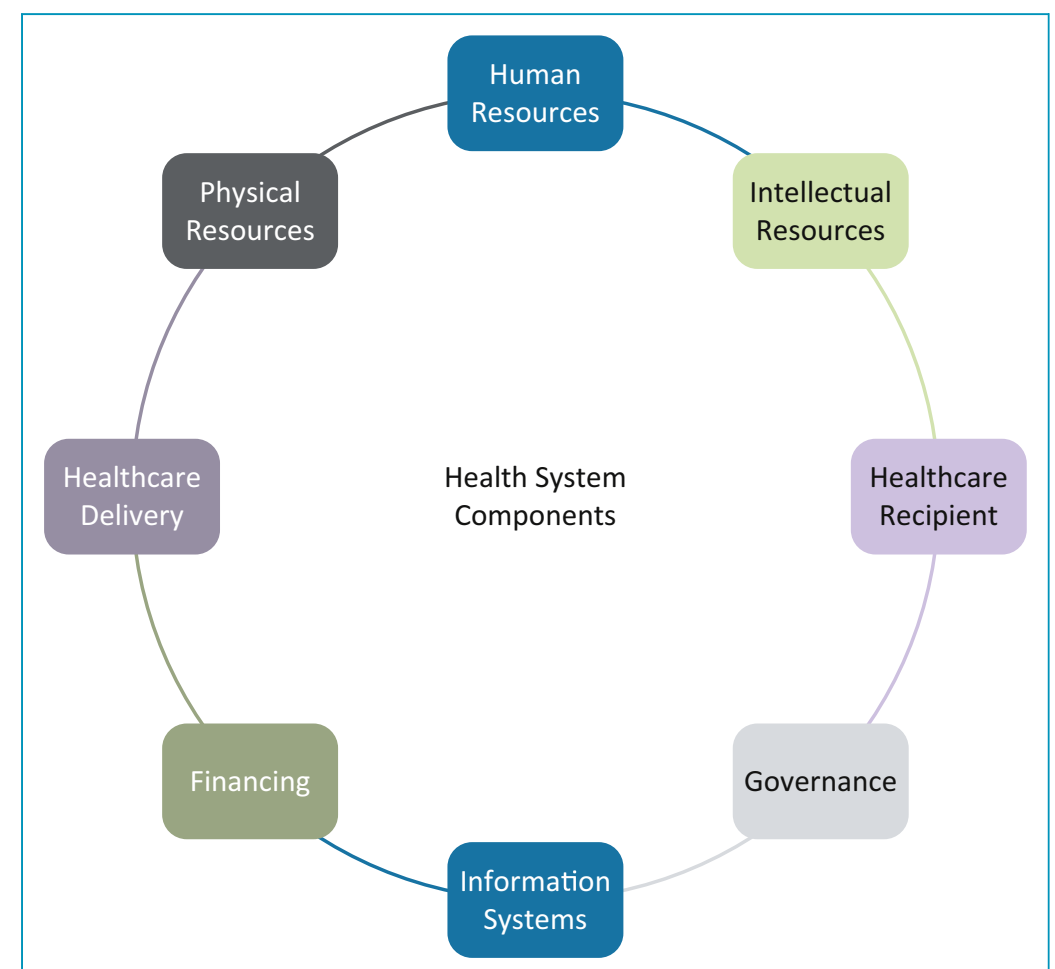

FIGURE 1. Health system requirements to achieve secondary prevention targets. Reproduced with permission from Perel et al. [15].

Regarding the role of primary care providers on the care delivery in substantial proportion of secondary prevention, especially outside the large cities and in poorer regions where there are fewer cardiologists, understanding and proposing how they might be reached and included in these efforts represents a key challenge. In fact, we would like to suggest that based on the $25 \times 25$ Roadmap launched in Brazil, the Family Health Strategy, linked to the Universal Health Coverage of the Brazilian Health System, should definitely include health workers in order to identify patients with secondary prevention eligibility and to reassure the best possible adherence rates for evidence-based medications. Consequently, the inclusion of the health system component, ideally through health workers for the implementation of strategies for CVD secondary prevention is highly recommended for a successful nationwide preventive program.

Finally, nongovernmental organizations serve as strategic partners and can support and deliver robust technical assistance. Such technical assistance must be evidencebased and action-oriented and include the CVD prevention and management. The customization of the WHF Roadmaps are complementary to the WHO Global Action Plan for NCD prevention and control, and their implementation in LAC will allow us to positively influence the significant burden of CVD over the next 10 years. 


\section{ACKNOWLEDGMENTS}

The authors deeply appreciate the contributions to preparing this manuscript from the following people: Diandro Motta and Felipe Malafaia from the Research Division of Dante Pazzanese Institute of Cardiology, São Paulo, Brazil, and Dr. Anselm Hennis from PAHO/WHO.

\section{REFERENCES}

1. Barquera S, Pedroza-Tobias A, Medina C, et al. Global overview of the epidemiology of atherosclerotic cardiovascular disease. Arch Med Res 2015;46:328-38.

2. Institute for Health Metrics and Evaluation. Global Burden of Disease Study 2010 (GBD 2010) Results by Cause 1990-2010-Country Level. Seattle, WA: Institute for Health Metrics and Evaluation; 2013.

3. PAHO. Deaths due to noncommunicable diseases in countries of the Americas. Available at: http://www.paho.org/hq/index.php?option= com_content\&view=article\&id=10169\%3A2014-deaths-due-to-non communicable-diseases-in-countries-of-the-americas $\&$ catid $=7237 \%$ 3Ainfo\&ltemid=41161\&lang=en; 2014. Accessed January 28, 2016.

4. De Fatima Marinho de Souza M, Gawryszewski VP, Ordunez $P$, Sanhueza A, Espinal MA. Cardiovascular disease mortality in the Americas: current trends and disparities. Heart 2012;98:1207-12.

5. Ordunez P, Prieto-Lara E, Pinheiro Gawryszewski V, Hennis AJ, Cooper RS. Premature mortality from cardiovascular disease in the Americas - will the goal of a decline of " $25 \%$ by 2025 " be met? PLoS One 2015;10:e0141685.

6. Roth $\mathrm{GA}$, Forouzanfar $\mathrm{MH}$, Moran $\mathrm{AE}$, et al. Demographic and epidemiologic drivers of global cardiovascular mortality. N Engl J Med 2015;372:1333-41.

7. Kreatsoulas C, Anand SS. The impact of social determinants on cardiovascular disease. Can J Cardiol 2010;26(Suppl C):8C-13C

8. The NCD Alliance. The Global Burden of NCDs: The Global Epidemic. NCD Alliance. Available at: https://ncdalliance.org/printpdf/theglobal-epidemic 2010. Accessed March 1, 2016.

9. Suhrcke M, Nugent RA, Stuckler D, Rocco L. Chronic disease: an economic perspective. Available at: http://www.sehn.org/tccpdf/Chronic \%20disease\%20economic\%20perspective.pdf; 2006. Accessed March 1, 2016

10. Bloom DE, Cafiero ET, Jane-Llopis E, et al. The Global Economic Burden of Noncommunicable Diseases. Geneva, Switzerland: World Economic Forum; 2011.

11. Atun R, de Andrade LO, Almeida G, et al. Health-system reform and universal health coverage in Latin America. Lancet 2015;385: 1230-47.

12. Smith SC Jr, Benjamin EJ, Bonow RO, et al. AHA/ACCF secondary prevention and risk reduction therapy for patients with coronary and other atherosclerotic vascular disease: 2011 update: a guideline from the American Heart Association and American College of Cardiology Foundation endorsed by the World Heart Federation and the Preventive Cardiovascular Nurses Association. J Am Coll Cardiol 2011;58:2432-46.

13. Yusuf S. Two decades of progress in preventing vascular disease. Lancet 2002;360:2-3.

14. Lim SS, Gaziano TO, Gakidou E, et al. Prevention of cardiovascular disease in high-risk individuals in low-income and middle-income countries: health effects and costs. Lancet 2007;370:2054-62.

15. Perel $P$, Avezum $A$, Huffman $M$, et al. Reducing premature cardiovascular morbidity and mortality in people with atherosclerotic vascular disease: the World Heart Federation Roadmap for Secondary Prevention of Cardiovascular Disease. Glob Heart 2015;10:99-110.

16. O'Gara PT, Kushner FG, Ascheim DD, et al. 2013 ACCF/AHA guideline for the management of ST-elevation myocardial infarction: a report of the American College of Cardiology Foundation/American Heart Association Task Force on Practice Guidelines. J Am Coll Cardiol 2013; 61:e78-140.

17. Steg $P G$, James $S K$, Atar $D$, et al. ESC guidelines for the management of acute myocardial infarction in patients presenting with ST-segment elevation. Eur Heart J 2012;33:2569-619.
18. IV guidelines of Sociedade Brasileira de Cardiologia for treatment of acute myocardial infarction with ST-segment elevation. Arq Bras Cardiol 2009;93(Suppl 2):e179-264.

19. Amsterdam EA, Wegner NK, Brindis RG, et al. 2014 AHA/ACC guideline for the management of patients with non-ST-elevation acute coronary syndromes: executive summary: a report of the American College of Cardiology/American Heart Association Task Force on Practice Guidelines. Circulation 2014;130:2354-94.

20. Nicolau JC, Timerman A, Marin-Neto JA, et al. Guidelines of Sociedade Brasileira de Cardiologia for unstable angina and non-STsegment elevation myocardial infarction (II edition, 2007) 2013-2014 update. Arq Bras Cardiol 2014;102(Suppl 1):1-61.

21. Windecker S, Kohl P, Alfonso F, et al. 2014 ESC/EACTS guidelines on myocardial revascularization: the Task Force on Myocardial Revascularization of the European Society of Cardiology (ESC) and the European Association for Cardio-Thoracic Surgery (EACTS) developed with the special contribution of the European Association of Percutaneous Cardiovascular Interventions (EAPCI). Eur Heart J 2014;35: 2541-619.

22. Kulik A, Ruel $M$, Jneid $H$, et al. Secondary prevention after coronary artery bypass graft surgery: a scientific statement from the American Heart Association. Circulation 2015;131:927-64.

23. Perk J, De Backer G, Gohlike H, et al. European guidelines on cardiovascular disease prevention in clinical practice (version 2012): the Fifth Joint Task Force of the European Society of Cardiology and Other Societies on Cardiovascular Disease Prevention in Clinical Practice (constituted by representatives of nine societies and by invited experts). Eur Heart J 2012;33:1635-701.

24. Yusuf S, Hawken S, Ounpuu S, et al., for the INTERHEART Study Investigators. Effect of potentially modifiable risk factors associated with myocardial infarction in 52 countries (the INTERHEART study): case-control study. Lancet 2004;364:937-52.

25. O'Donnell MJ, Xavier D, Liu L, et al., for the INTERSTROKE Investigators. Risk factors for ischaemic and intracerebral haemorrhagic stroke in 22 countries (the INTERSTROKE study): a case-control study. Lancet 2010;376:112-23.

26. Chow CK, Jolly S, Rao-Melacini P, Fox KA, Anand SS, Yusuf S. Association of diet, exercise, and smoking modification with risk of early cardiovascular events after acute coronary syndromes. Circulation 2010;121:750-8.

27. Iqbal R, Anand S, Ounpuu $S$, et al., for the INTERHEART Study Investigators. Dietary patterns and the risk of acute myocardial infarction in 52 countries: results of the INTERHEART study. Circulation 2008;118:1929-37.

28. Grainger Gasser A, Welch C, Arora M, et al. Reducing cardiovascular mortality through tobacco control: a World Heart Federation Road map. Glob Heart 2015;10:123-33.

29. Alberts MJ, Bhatt DL, Mas JL, et al., for the REACH Registry Investigators. Three-year follow-up and event rates in the international REduction of Atherothrombosis for Continued Health Registry. Eur Heart J 2009;30:2318-26.

30. Rodriguez F, Cannon CP, Steg PG, et al., for the REACH Registry Investigators. Predictors of long-term adherence to evidence-based cardiovascular disease medications in outpatients with stable atherothrombotic disease: findings from the REACH Registry. Clin Cardio 2013;36:721-7.

31. Yusuf S, Islam S, Chow CK, et al., for the PURE Study Investigators Use of secondary prevention drugs for cardiovascular disease in the community in high-income, middle-income, and low-income countries (the PURE Study): a prospective epidemiological survey. Lancet 2011;378:1231-43.

32. Teo K, Lear $\mathrm{S}$, Islam $\mathrm{S}$, et al., for the PURE Investigators. Prevalence of a healthy lifestyle among individuals with cardiovascular disease in high-, middle- and low-income countries: the Prospective Urban Rural Epidemiology (PURE) study. JAMA 2013;309:1613-21.

33. Hospedales CJ, Barcelo A, Luciani S, Legetic B, Ordunez P, Blanco A. NCD prevention and control in Latin America and the Caribbean: a regional approach to policy and program development. Glob Heart 2012;7:73-81. 
34. Khatib R, McKee M, Shannon $H$, et al., for the PURE Study Investigators. Availability and affordability of cardiovascular disease medicines and their effect on use in high-income, middle-income, and low-income countries: an analysis of the PURE study data. Lancet 2016;378:61-9.

35. PAHO. Plan of Action for the Prevention and Control of Noncommunicable Diseases in the Americas 2013-2019. Washington, DC: PAHO; 2014.

36. Ordunez P, Mize V, Barbosa M, Legetic B, Hennis AJ. A rapid assessment study on the implementation of a core set of interventions to improve cardiovascular health in Latin America and the Caribbean. Glob Heart 2015;10:235-240.e2.

37. Ordunez P, Luciani S, Barojas A, Fitzgerald J, Hennis AJ. A public health approach to hypertension. Lancet 2015;385:1833.
38. Saillour-Glenisson F, Michel P. Individual and collective facilitators of and barriers to the use of clinical practice guidelines by physicians: a literature review. Rev Epidemiol Sante Publique 2003;51: 65-80.

39. Francke AL, Smit MC, de Veer AJ, Mistiaen P. Factors influencing the implementation of clinical guidelines for health care professionals: a systematic meta-review. BMC Med Inform Decis Mak 2008;8:38.

40. WHO. Package of Essential NCD Interventions for Primary Health Care: Cancer, Diabetes, Heart Disease and Stroke, Chronic Respiratory Disease. Geneva, Switzerland: WHO; 2010.

41. WHO. Global Hearts Initiative: Working Together to Beat Cardiovascular Diseases. Available at: www.who.int/cardiovascular_diseases/ global-hearts/en/. Accessed May 1, 2016 